\title{
Communicating Familial Risks: Individual and Community Issues Involved in Cancer Genetics
}

\author{
Claire Julian-Reynier \\ INSERM U379, Marseille, France
}

A small percentage of all the occurrences of the "serial killer' diseases with which our present-day societies are beset, such as cancer, cardiovascular diseases, infectious diseases and neurological disorders [1], among others, can now be said to come within the scope of predictive genetics. One of the main challenges faced in this first decade of the 21 st century is how to integrate the latest genetic knowledge into common medical practice. The introduction of genetic factors into our overall picture of common diseases has greatly enlarged the scale on which traditional genetics work because of the large numbers of people involved in our populations. More than half of all adults in their sixties have at least one case of cancer to report among their first-degree relatives [2], and everybody is likely to be involved in genetic issues if we also include cardiovascular and neurological disorders.

The ability to communicate information about familial risks is therefore a key point worth considering. The papers in this special issue of Community Genetics deal with some of the problems involved in communicating breast/colorectal cancer risk information. The authors of these studies all belong to a collaborative network set up within the framework of a European project focusing on cancer risk communication $[3,4]$.

Introducing new genetic findings into clinical practice by organising specific consultations to inform people about the cancer risks possibly running in their family is a newly emerging form of clinical practice. It requires the participation of networks of two particular kinds. Those of the first kind are networks of health care providers, namely medical specialists in the fields of cancer and genetics. The first paper in this special issue describes the case of the 'CRISCOM' network and explains how seven centres (in Haifa, Hannover, Leiden, Leuven, Marseilles, Manchester and Milan) have been carrying out their clinical and biological practice since the end of the 1990s in Europe and Israel [5]. The authors point out the differences and similarities between countries in terms of the health professionals involved and the laboratory issues arising, as well as stressing the importance of a multidisciplinary approach to the organisation of these activities. This article shows in particular the links existing between research and clinical practice. The second type of network in question is the referring network. The referring providers can be specialists, general practitioners or nurses, depending on how the health care system is organised. Welkenhuysen and Evers-Kiebooms [6] describe here the reactions of general practitioners, nurses and midwives to breast cancer genetic information and, in particular, their attitudes towards the testing and management of high-risk women.

\begin{tabular}{ll}
\hline KARGER & ( ) 2003 S. Karger AG, Basel \\
Fax +4161306 1234 & 1422-2795/03/0064-0189\$19.50/0 \\
$\begin{array}{l}\text { E-Mail karger@karger.ch } \\
\text { www.karger.com }\end{array}$ & $\begin{array}{l}\text { Accessible online at: } \\
\text { www.karger.com/cmg }\end{array}$
\end{tabular}

Dr. Claire Julian-Reynier
INSERM U379, Institut Paoli-Calmettes
232 Bd Sainte Marguerite
FR-13009 Marseille (France)
Tel. +33 491 223502, Fax +33 491 223504, E-Mail julian@marseille.inserm.fr 
Cancer genetic consultations are a fairly recent development, but they are still being run on traditional genetics lines in terms of information giving and counselling [7]. How risks should be presented is a complex issue, and Hopwood et al. [8] report here on their clinical experience, presenting risks in terms of proportions (odds) and odds ratios. These authors state that this format is well understood in the United Kingdom. The effectiveness of the various ways of formatting risks is still being discussed in the literature, and women's preferences in various countries have not yet been properly documented [4]. Investigating these preferences will be one of the next steps in the CRISCOM project.

Cypowyj et al. [9] look at the information sources that women use on their own during the genetic testing process. They also describe the interactions which occur between these women and their social network, relatives and doctors when they are exchanging opinions about breast/ovarian cancer genetic testing. Here, the central role of cancer geneticists is highlighted, both as information providers and as the main persons with whom women can discuss what they feel about genetic testing.

The reasons why it is necessary to assess and communicate information about breast/ovarian cancer risks include the fact that this procedure helps to guide the decisions which have to be made about the surveillance and prevention options available. However, recommendations about surveillance and prevention tend to differ from one country to another, even when they are based on similar clinical findings [10, 11]. In this issue, van Dooren et al. [12] present results obtained regarding the link between the frequency with which breast self-examination is carried out by women with breast cancer in their families and their level of anxiety, stratifying the results according to the level of cancer risk. Apart from the fact that women can be guided differently in one country compared to another, or depending on which providers they consult, the finding that highrisk women with high anxiety levels carried out breast selfexamination much too frequently is of clinical significance, since it means that highly distressed women should be identified in order to provide them with some extra support. It also suggests that breast self-examination might have stressful side effects.

The psychological and behavioural effects of BRCA genetic testing is a crucial issue on which the results of ongoing prospective studies will throw light. Women's social and preventive behaviour and their perception of the results of these tests as a stressful life event were not found to differ depending on their carrier versus non-carrier status [13].
Since identifying a deleterious BRCA mutation in newly consulting families where a direct gene mutation search is not indicated is an expensive and technically difficult step, the question as to whether this information should be conveyed to the families via the first individual tested is of great importance. Nippert and Schlegelberger [14] have contributed to this special issue by outlining the German approach to cancer genetic testing and describing how some of the individuals involved reacted to the idea of conveying this information to their family. In particular, these authors established that women with positive test results were more reluctant to transmit this information than those with negative results.

After Huntington's disease, which was the precursor, and neurological disorders, which followed on, the field of clinical oncology is one of the pioneer examples of how predictive genetics can be applied to common disorders. The difference here is that the predictive approach makes it possible in the case of familial cancer to diagnose the disease at an earlier stage, with a better prognosis, or even to prevent its occurrence altogether. However, given the undesirable side effects of preventive surgery [15], which is the only strategy reported so far in the literature to be really effective, and the lack of evidence supporting the benefits of the screening strategies available, a great deal of research is still required at both the clinical and community levels. One of the main aims of the present issue is to encourage research workers focusing on these important issues to continue to pursue their efforts along these lines in order to improve our knowledge of the factors involved in the use of these predictive strategies and the advantages to be gained by patients. 


\section{References}

1 Khoury M, Burke W, Thomson EJ: Genetics and Public Health in the 21st Century: Using Genetic Information to Improve Health and Prevent Disease. Oxford, Oxford University, 2000.

2 Pinsky PF, Kramer BS, Reding D, Buys S; PLCO Project Team: Reported family history of cancer in the prostate, lung, colorectal, and ovarian cancer screening trial. Am J Epidemiol 2003; 157:792-799.

3 European Commission: Risk communication in cancer genetics: Lay people's expectations and providers' practices (CRISCOM); in Martins Bossier A, Kütt W, Joliff-Botrel G (eds): Strategic Accompanying Measures, Catalogue of Contracts (1999-2002). Luxembourg, European Communities, 2003, p 55.

4 Julian-Reynier C, Welkenhuysen M, Hagoel L, Decruyenaere M, Hopwood P; CRISCOM Working Group: Risk communication strategies: State of the art and effectiveness in the context of cancer genetic services. Eur J Hum Genet 2003;11:725-736.

5 Hopwood P, van Asperen CJ, Borreani G, Bourret P, Decruyenaere M, Dishon S, Eisinger F, Evans GDR, Evers-Kiebooms G, Gangeri L, Hagoel L, Legius E, Nippert I, Rennert G, Schlegelberger B, Sevilla C, Sobol H, Tibben A, Welkenhuysen M, Julian-Reynier C: Cancer genetics service provision: A comparison of seven European centres. Community Genet 2003;6:192-205.
6 Welkenhuysen M, Evers-Kiebooms G: The reactions of general practitioners, nurses and midwives in Flanders concerning breast cancer risks in a high-risk situation. Community Genet 2003;6:206-213.

7 Kessler S: Psyche and Helix: Psychological Aspects of Genetic Counseling. New York, Wiley, 2000.

8 Hopwood P, Howell A, Lalloo F, Evans G: Do women understand the odds?: Risk perceptions and recall of risk information in women with a family history of breast cancer. Community Genet 2003;6:214-223

9 Cypowyj C, Eisinger F, Morin M, Mogoutov A, Sobol H, Julian-Reynier C: Information-seeking behaviour and psycho-social interactions during the genetic testing process. Community Genet 2003;6:224-234

10 Bouchard L, Blancquaert I, Eisinger F, Foulkes W, Evans D, Sobol H, Julian-Reynier C: Prevention and genetic testing for breast cancer: Variations in medical decisions. Soc Sci Med 2004:58:1085-1096.
11 Eisinger F, Geller G, Burke W, Holtzman NA Cultural basis for differences between US and French clinical recommendations for women at increased risk of breast and ovarian cancer. Lancet 1999;353:919-920.

12 van Dooren S, Rijnsburger AJ, Seynaeve C, Kriege A, Duivenvoorden HJ, Bartels CCM, Essink-Bot ML, de Koning HJ, Tibben A: Psychological distress and breast self-examination frequency in women at increased risk for hereditary or familial breast cancer. Community Genet 2003;6:235-241.

13 Hagoel L, Neter E, Dishon S, Barnett O, Rennert G: BRCA1/2 mutation carriers: Living with susceptibility. Community Genet 2003;6: 242-248.

14 Nippert I, Schlegelberger B, and the members of the Consortium 'Hereditary Breast and Ovarian Cancer of the Deutsche Krebshilfe': Women's experiences of undergoing BRCA1 and BRCA2 testing: Organisation of the German Hereditary Breast and Ovarian Cancer Consortium survey and preliminary data from Münster. Community Genet 2003;6:249-258.

15 van Oostrom I, Meijers-Heijboer H, Lodder LN, Duivenvoorden HJ, van Gool AR, Seynaeve C, van der Meer CA, Klijn JG, van Geel BN, Burger CW, Wladimiroff JW, Tibben A Long-term psychological impact of carrying a BRCA $1 / 2$ mutation and prophylactic surgery: A 5-year follow-up study. J Clin Oncol 2003; 21:3867-3874. 